\title{
OPPORTUNITY RECOGNITION: DELINEATING THE PROCESS AND MOTIVATORS FOR SERIAL ENTREPRENEURS
}

\author{
B Urban
}

Wits Business School, University of the Witwatersrand

\begin{abstract}
Opportunity recognition is a fundamental research issue in entrepreneurship which this paper empirically investigates for serial entrepreneurs. Initially key definitions and boundary conditions of opportunity recognition are explored to elucidate the relevant motivators driving serial entrepreneurs. After operationalising the various concepts, data are collected by surveying serial entrepreneurs $(n=77)$ based on pre-determined selection criteria. Since the study's objective is to build solid theory on these new phenomena, descriptive analysis on the empirical results is provided. To test the hypotheses inferential statistics employing parametric and non-parametric tests are used. The findings reveal that the opportunity recognition behaviours are manifest among serial entrepreneurs, with few significant differences on how many new, major businesses have been pursued, or whether they can be said to be successes.
\end{abstract}

Abstract

JEL D8, J24, L26, M13

\section{1 \\ Introduction}

Opportunity recognition is a fundamental research issue in entrepreneurship research (Gaglio \& Katz, 2001; Shane \& Venkataraman, 2000). It is viewed as an important entrepreneurial capability (Ardichvili, Cardoza \& Ray, 2003), a source of competitive advantage (Alvarez \& Busenitz, 2001), and an important component of entrepreneurship education (De Tienne \& Chandler, 2004; Kourilsky, 1995). Shane and Venkataraman (2000) make a compelling argument that entrepreneurial opportunity recognition and exploitation are constructs that fall within the unique domain of entrepreneurship and should be the central focus of research in the field. The fundamental activity of entrepreneurship is new venture creation (Gartner, 1990), and new venture creation is a process (e.g., Bygrave \& Hofer, 1991; Lumpkin \& Dess, 1996). Opportunity recognition is at the beginning of this entrepreneurship process.

Understanding the opportunity recognition process represents one of the core intellectual questions for the domain of entrepreneurship (Gaglio \& Katz, 2001). Shane and Venkataraman (2001: 11) suggest research focus on the central question of the entrepreneur - why, when and how some people and not others discover and exploit opportunities. This call coincides with their definition which views the field of entrepreneurship as a "scholarly examination of how, by whom, and with what effects opportunities to create future goods and services are discovered, evaluated and exploited" (Shane \& Venkataraman, 2000: 218).

Individuals and opportunities are first order forces explaining entrepreneurship and environmental forces second order, which might moderate the effects of the nature of the individual and opportunities but they cannot explain it. Why, when and how certain individuals exploit opportunities appears to be a function of both the opportunity and the nature of the individual (Shane \& Venkataraman, 2000). In this newly emerging area of inquiry, several studies have explored the role that human capital plays in opportunity identification (Davidsson \& Honig, 2003; Ucbasaran, Westhead \& Wright, 2001). 
Empirical research has shown that the ability to identify opportunities is related to such human capital variables as education, work experience, entrepreneurial experience (Davidsson \& Honig, 2003), prior knowledge (Shane, 2000), prior knowledge of customer problems (Shepherd \& DeTienne, 2005), experiential knowledge (Dimov, 2007), and previous entrepreneurial experience (Ucbasaran et al., 2001). Moreover, the ability to identify opportunities is a cognitive task that allows some individuals, though not others, to identify opportunities (Shane \& Venkataraman, 2000). Individuals are thought to identify opportunities because they possess uniquely different forms of knowledge or human capital (Venkataraman, 1997).

Further to this exploration on theoretical issues of opportunity recognition the concept of serial entrepreneurs is highly relevant since opportunity recognition is a key trait that serial entrepreneurs seem to be very competent at, they are generally adept towards opportunity recognition (Taplin, 2004). They are generally more "fine tuned" to identify opportunities than inexperienced entrepreneurs. This would suggest that serial entrepreneurs know how and where to obtain useful information, how to interpret and analyse this information to make sound business decisions, and when and how to act appropriately (Lumpkin, Hills \& Shrader, 2004; Taplin, 2004). In general, little is known about serial entrepreneurs, particularly in South Africa, even though researchers agree that there are many benefits that can be gained and lessons learned from studying and understanding this special breed of entrepreneur (Lumpkin, Hills \& Shrader, 2004). Although there seems not to be a generally accepted definition of serial entrepreneurship, some researchers (Westhead \& Wright, 1998) refer to them as venture repeaters, i.e., individuals who have sold or closed their original businesses but at a later date have inherited, established, and/or purchased other businesses. These individuals own one business after another but effectively own only one business at a time.

\section{2}

\section{Literature review}

Scholars have not agreed on a definition for what constitutes an entrepreneurial opportunity or whether opportunities are "identified", "recognised," or "created." Some of the inconsistencies in the early research may be due to what Feldman (2004: 566) refers to as the failure to "clearly, precisely, and succinctly define key constructs." Consequently, key definitions and boundary conditions of opportunity recognition are explored to elucidate the subject under research. Singh (2000: 11), states that an "entrepreneurial opportunity is a feasible, profit-seeking, potential venture that provides an innovative new product or service to the market, improves on an existing product/service, or imitates a profitable product/service in a less-than-saturated market." Here Singh (2000) purposefully chose the word "identification" rather than "recognition" or "creation." According to Singh, recognition carries with it a presumed ontological perspective that opportunities "exist out there" and it is the entrepreneur's role to recognise them (Drucker, 1998). Creation limits opportunities to only those that the entrepreneur creates. According to Singh (2000), while elements of opportunities may be "recognised" opportunities are made, not found. Identification seems a more inclusive term that encompasses both potential opportunities already existing in the environment and opportunities that are created by the entrepreneur. The phenomenon of opportunity identification is highly complex, and existing studies in the area cut across a broad range of disciplines including management, organisation theory, marketing, and entrepreneurship (Lumpkin, Hills \& Shrader, 2004). Entrepreneurs identify business opportunities to create and deliver value for stakeholders in prospective ventures.

It has been suggested that the opportunity identification process begins when alert entrepreneurs notice factors in their domain of expertise that result in the recognition and evaluation of potential business opportunities (Ardichvili et al., 2003). Corbett (2007) extends 
this line of inquiry by examining the relationship between opportunity identification and learning. Here Corbett develops the concept of learning asymmetries and explains how the manner in which people learn may affect their ability to identify entrepreneurial opportunities.

Lumpkin, Hills and Shrader (2004) argue that the creation of successful businesses follows successful opportunity development and also involves the entrepreneur's creative work. Therefore, "opportunity development" rather than "opportunity recognition" should be the focus. The need or resource "recognised" or "perceived" cannot become a viable business without this "development." This opportunity development process includes recognition of an opportunity, its evaluation, and development. The need or resource "recognised" or "perceived" cannot become a viable business without this "development."

Moreover, opportunity recognition may be the result of systematic search (Vesper, 1996) and/or careful strategic planning (Timmons, 1994). Opportunity recognition consists of either perceiving a possibility to create new businesses, or significantly improving the position of an existing business, in both cases resulting in a new profit potential. A model of opportunity recognition developed by Hills, Schrader and Lumpkin (1999) suggests theory from the creativity and psychology literature form the basis of this model.

Opportunity recognition may be seen as a series of steps involving iteration of creative thinking; or opportunity identification as the creative stage of the entrepreneurial model; and some have described opportunity recognition as including the actual creation of a new venture (Bhave, 1994). The creation perspective is consistent with the ontological perspective that opportunities are a product of one's mind.

Many researchers have developed conceptual models of the opportunity recognition process (e.g., Bhave, 1994; Gaglio \& Katz, 2001; Lumpkin, Hills, \& Shrader, 2004; Singh, 2000), with Bhave (1994) proposing a process model of venture creation with opportunity recognition being the key early stage in the sequence of events leading to the creation of the venture. Moreover, as Gaglio and Katz (2001) point out, the typical process is portrayed as having four major steps: (1) the pre-recognition stage, (2) the eureka experience, (3) further development of the idea, and (4) the decision to proceed. Similarly, Chandler, Lyon, and DeTienne (2005) identify the following four opportunity identification processes: (1) learn/ replicate, (2) learn/innovate, (3) learn/acquire, and (4) innovate/educate; moreover they show that differences in human capital are related to the selection and application of different opportunity identification processes.

Major factors that influence this core process of opportunity recognition and development leading to business formation include: entrepreneurial alertness, information asymmetry and prior knowledge, social networks, personality traits, including optimism and self-efficacy, and creativity; and type of opportunity itself (Hills \& Singh, 2004).

Bhave (1994), in formulating a process model of venture creation, found two types of opportunity recognition. The first category, externally stimulated opportunities are those where the decision to start a business precedes opportunity recognition. Entrepreneurs who recognise the opportunities for their ventures using this process presumably engage in an ongoing search for opportunities, which they filter, massage, and elaborate on before founding their firms. The second category, internally stimulated opportunity recognition happens when entrepreneurs first have a business idea, discovering problems to solve or needs to fulfil, and only later decide to create ventures.

In general, people discover opportunities that others do not identify for two reasons: first, they have better access to information about the existence of the opportunity. Second, they are better able than others to recognise opportunities, given the same amount of information about it, because they have superior cognitive capabilities (Krueger, 2000).

Having experience and knowledge within an industry facilitates entrepreneurs recognising market gaps and assessing the market potential of new venture (Singh, 2000). Additionally social encounters are a source of venture ideas (Christensen \& Peterson, 1990) and thus can lead to opportunity recognition. 
Further, it is possible that certain opportunity recognition behaviours and actions help reduce the liability of newness and improve the chances for success. Failures and false starts are a normal part of the opportunity recognition process, and the knowledge gained from such experiences often leads to future gains that are more solid (Hills \& Singh, 2004).

These above-mentioned findings suggest that opportunity recognition is a critically important aspect of the new venture formation process. Entrepreneurs with prior knowledge of a given domain are alert to opportunities in that business environment. "Opportunity recognition" appears to include three distinct processes: (1) sensing or perceiving market needs and/or underemployed resources, (2) recognising or discovering a "fit" between particular market needs and specified resources, and (3) creating a new "fit" between heretofore separate needs and resources in the form of a business concept (Hills \& Singh, 2004: 264). It seems safe to deduce from the above discourse that these processes represent, respectively, perception, discovery, and creation - not simply "recognition" (Christensen \& Peterson, 1990).

Opportunity recognition is of particular importance to serial entrepreneurs (Taplin, 2004). Due to the reiterative nature of their entrepreneurial behaviour, they have more competence in recognising opportunities than inexperienced entrepreneurs (Lumpkin, Hills \& Shrader, 2004; Taplin, 2004). Serial entrepreneurs own a very large number (more than one third) of new firms in many countries (Birley \& Westhead, 1994). Taplin (2004: 248) suggests that 41 per cent of high-growth companies in Europe's 500 List have been founded by serial entrepreneurs. Similarly, 81 per cent of the CEOs of Americas Inc. 500 list of high growth companies started their businesses with a plan to go public or sell out to another company after some time, which suggests serial entrepreneurial behaviour. Correspondingly in the United Kingdom 12 per cent to 36 per cent of new businesses were founded by serial entrepreneurs.

According to Taplin (2004) serial entrepreneurial behaviour falls into two broad groups: venture repeaters (this group tends to be reactive, effectively undertaking a second venture because there were few obvious alternatives), and opportunist serial ventures (this group has common features in that capital gain and the challenge of developing a business are frequently important factors). Low and MacMillan (1998) point out that networks are an important aspect of the entrepreneurship context and process. They suggest that the serial entrepreneur may be less likely to engage in proactive search strategies because he can draw upon experiences that worked well in the past and tap into the information and contacts (i.e. networks) for potential opportunities. Westhead and Wright (1998) suggest that serial founders generally use more sources of financing than other types of entrepreneurs.

Other related categorisations to serial entrepreneursinclude:(1)Habitual entrepreneurs (Wright et al., 1997): Also referred to as business generators and experienced founders. They start or purchase several businesses at one time or sequentially and are identified on the basis of two dimensions: whether a new or existing business is involved and whether the entrepreneurial act is sequential (serial) or concurrent (portfolio) (Ucbasaran et al., 2001); and (2) Portfolio entrepreneurs (a subset of "habitual entrepreneurs"), also referred to as multiple (business) entrepreneurs and parallel entrepreneurs. These are individuals who have established more than one business but still own the most recent businesses established prior to the start-up of their current, new, and/or independent ventures (Taplin, 2004). These different types of entrepreneurs tend to have unique motivations for their chosen activities. Serial entrepreneurs tend to have stronger preferences for innovation, greater propensity for risk-taking, and a higher need for achievement than do novice (or first-time) entrepreneurs (Lumpkin, Hills \& Shrader, 2004; Taplin, 2004). Non financial/intrinsic motivations have also been identified as reasons for involvement in serial entrepreneurship (Birley \& Westhead, 1994; Douglas \& Shepherd, 2003).

Among serial entrepreneurs, a common reason for a starting a first venture is the frustration resulting from working in large, bureaucratic, 
and political organisations (Ucbasaran et al., 2001). Serial entrepreneurs may also start a new venture or explore purchasing an existing business. For their second ventures, the key motivational factors tend to be the desire to build up a successful business (or turn around a non-successful one), limit their financial risk, and face the challenge of continuing to succeed in their entrepreneurial activities. Some serial entrepreneurs go directly to their next ventures and some take an indirect path via periods of employment, extended vacations, and other projects. Common motivations for the second start up include the desire to continue the challenge of owning a successful business, the desire to work closer to family, and the desire to benefit from tax breaks. Wright, Westhead and Sohl (1997) argue that serial entrepreneurs typically desire to exit from an initial venture when entrepreneurial opportunities are perceived to have been exhausted. Once they leave the firm, they search for new possibilities with a new venture. Serial entrepreneurs are known to start several firms, some of which are successful and others are not.

\section{3}

\section{Research problem and aims}

The overall research objective was to determine serial entrepreneurs' perceptions of their opportunity recognition behaviours and motivators. Due to the limited understanding of the opportunity recognition behaviours and the concomitant motivations that serial entrepreneurs hold for their first and later ventures, the importance of all these factors needs to be understood so that the behaviour of this important category of entrepreneurs can be replicated. To address the issue of how serial entrepreneurs recognise opportunities and what drives the serial nature of their behaviour, the research question this paper poses is: what are serial entrepreneurs' opportunity recognition behaviours and what are the motivators that serial entrepreneurs hold for their first and later ventures.

Based on the theoretical underpinnings in the literature review, the following hypotheses are formulated and set at the 0.05 significance level (p-value $<0.05$ ):
Null Hypothesis 1: Opportunity recognition behaviours and motivators of serial entrepreneurs will not differ depending on how many new, major businesses have been pursued.

Null Hypothesis 2: Opportunity recognition behaviours and motivators of serial entrepreneurs will not differ depending on how many of these businesses can be said to be successes.

Null Hypothesis 3: Opportunity recognition behaviours and motivators of serial entrepreneurs will not differ depending on how many of these businesses were unrelated to an existing business at the time.

Ha: For all the hypotheses the alternatives state that there will be a difference depending on how many new, major businesses have been pursued; on how many of these businesses can be said to be successes; on how many of these businesses were unrelated to an existing business at the time.

4

\section{Nature of research}

A cross-sectional survey research design was used to collect quantitative data from respondents meeting pre-determined selection criteria. Questions were based on prior literature and selected items from previous studies by, Christensen and Peterson (1990), Kaish and Gilad (1991), and Hills, Shaver and Reynolds (1999) were replicated and modified.

Interrogating the study's research question will allow for descriptive data to collate concerning serial entrepreneurs' opportunity recognition behaviours. The process of building solid theory begins by describing the phenomena that one wants to understand, after which once the phenomena has been thoroughly characterised, the researcher can begin to classify the phenomena into categories to more meaningfully understand the complex array of relationships between the phenomena and then articulate a theory that asserts what causes the phenomena and why (Street \& Cameron, 2007).

Since existing work has not yielded generalisable knowledge pertaining to the fundamental nature of opportunity recognition 
behaviours for different groups of entrepreneurs, it was posited that a descriptive study generating empirical results will add to the body of knowledge in this new direction of study.

\section{5}

\section{The sample frame}

Other researchers have noted the difficulty in obtaining a survey response in the entrepreneurial context (Davidsson, 2004). Serial entrepreneurs are not a well defined population, but rather a hazy and moving target (Davidsson, 2004). To offset this potential problem, and in the absence of a sampling frame, respondents were selected based on the definitions and related concepts of a serial entrepreneurs, as conceptualised in the literature review section. Good operational definitions are critical where sampling is not a simple matter (Cooper \& Emory, 1995). Moreover, in most respects the true definition of entrepreneurship is dependent on the nature of the sample selected to represent "entrepreneurs" (Gartner, 1989: 32).

The South African Business Guidebook (2005/2006) was used as a potential source of participants, where in the resources section institutions who are involved in assisting towards establishing small and medium businesses are mentioned. These include amongst others, institutions such as BRAIN (Business Referral and Information Network), DTI (Department of Trade and Industry), and the SA Institute of Intellectual Property Law. Although the sample is not representative of the small and medium business sector in South Africa in terms of industry sectors, enterprise sizes and regions, these serial entrepreneurs represent a dynamic set of entrepreneurs operating in the greater Johannesburg area (based in the Gauteng province, the economic hub of South Africa, which accounts for almost half of all enterprises in South Africa).

\section{6}

\section{The sample}

To qualify a respondent for inclusion as a serial entrepreneur, the leading criteria of having pursued (invested time and money) new, major business opportunities in the last five years was used. Based on these broad parameters, the survey concentrated on owner-managers in small-medium sized businesses with 50 up to 200 employees. This criterion meets the study's objective of how serial entrepreneurs are operationalised, as these are existing business owners pursuing 1, 2 or 3 , or 4 or more additional new business opportunities at the time they are already entrepreneurs. Those with existing ventures and prior experience in start-ups have a high propensity to engage in further ventures (Shane, 2000), and have the likelihood of being serial entrepreneurs. Serial entrepreneurs are generally proactive between first and second ventures in searching for a suitable opportunity (Taplin, 2004). This is an important issue, since sampling is not always statistical but about theoretical representativeness (Davidsson, 2004), i.e. the element in the sample represents the type of person that previous theory makes statements about.

A wide range of businesses were sampled which included; manufacturing, construction, financial, business, retail, motor trade and repair services, catering, accommodation and other trade, transport, storage and communications businesses. Based on eligibility criteria and employing a nonprobability judgemental sampling technique, 242 potential respondents were surveyed. The survey was solicited physically and electronically with periodic reminder telephone calls. A total of $\mathrm{N}=77$ qualified responses were secured (an effective 31 per cent response rate).

The sampling results for respondents are: male (79.2 per cent), female (20.8 per cent); educational attainment: (52 per cent) have a post-matric diploma and ( 21 per cent) have a first degree; the mean age statistic is 40 years old. These results correspond to previous findings on serial entrepreneurs, identifying those most likely to start a venture as men in mid 30s with tertiary education complete and established career record (this last variable was not measured for the present study).

\section{7}

\section{The measures}

Apart from the biographic details, the questionnaire consisted of the following three sections; 
number of businesses pursued (3 items), entrepreneurial opportunity recognition behaviours (6 items), and motivational items (18 items); apart from the ratio data all other items were measured on a 1-5 Likert scale, where $1=$ strongly disagree to $5=$ strongly agree.

The opportunity recognition behaviour (OPR) items were selected from the Panel Study of Entrepreneurial Dynamics (PSED) survey (Hills, Shaver \& Reynolds, 1999). Although it is acknowledged that OPR is highly complex, influenced throughout the entrepreneurial process by a variety of factors, e.g. human capital, networking, etc, for this present study OPR items focus exclusively on perceptions of opportunity recognition. Most models of OPR emphasise the importance of perceptions in opportunity recognition, and subsequently variables for the opportunity recognition processes are consistent with established conceptual frameworks discussed earlier in the literature review and include items on experience, learning and the creativity process.

Next, by extending the opportunity recognition debate, it seemed reasonable to assess the serial entrepreneur's motivations for starting first and subsequent ventures, and motivational items were split into "reasons which best describe reasons for your first venture" (10 items), and "reasons which best describe reasons for your successive venture" (8 items).

Moreover, questionnaire length, instructions to respondents, and anonymity were all considered in the final questionnaire design in order to generate a high response rate (Cooper \& Emory, 1995).

\section{8}

\section{Data analysis}

All the variables have been subjected previously to principal components factor analysis, with satisfactory results in terms of factor loadings (Carter, Reynolds \& Gartner, 2004). Nonetheless reliability was tested, and item statistics were calculated using the Cronbach's Alpha. The overall Cronbach Alphas for OPR items was 0.740 , and 0.856 for the motivational items.
Moreover, Chi-Square tests and symmetric measures of Phi, Cramer's V, and Kendall's tau-b, were used to identify any significant correlations between the various items; the OPR and motivator sections were paired to establish if the items measured some of the same issues, i.e. to ascertain if respondents answered the same way on specific issues. Based on the different sections, the cross-tab combinations yielded very few significant correlations, indicating that the items are not interrelated and generally measure separate concepts (Cooper \& Emory, 1995).

Applying tests for normality, by calculating the Kolmogorov-Smirnov and Shapiro-Wilk statistics, test scores indicated that normality was not violated. Based on the different sets of analysis, when the number of responses dropped below 30, non-parametric tests were used. The Kruskal-Wallis test is appropriate for data collected on ordinal and interval scale which do meet F-test assumptions or prove unsuitable for parametric tests (Cooper \& Schindler, 1995).

9

\section{Empirical results}

Descriptive statistics were calculated to provide an overview of the percentage responses for each question pertaining to the different measures. First for the number of opportunities pursued, refer to Table 1 . What emerges from Table 1 is that the majority of the sample (56 per cent) has pursued 2 or 3 businesses, with a resounding majority of these businesses being successful (64 per cent), and relatively few (14 per cent) of them were unrelated to existing businesses at the time. After an initial analysis due to the low response obtained for the two separate response categories, i.e. " 4 or 5" and "more than 5" businesses were collapsed into one category "4 or more". Due to further low numbers obtained on the last category " 4 or more", (see Table 1 ), the frequencies were re-coded and only the first question had sufficient responses for the " 4 or more" category.

Often researchers have to include people beyond those in whom they are interested (Cooper \& Emory, 1995), as was the case for this present sample, where respondents who 
answered that only one business opportunity was pursued in the last five years, were also included in the sample. The theoretical reasons for this were discussed earlier in the sample section (6). To test if there were any significant differences between respondents who answered only one business opportunity pursued versus those who answered more than one, a simple independent t-test between mean scores revealed no significant differences as the value was above 0.05 . Next the descriptive results for OPR items and the different motivators are provided in Table 2. Across all the sections, it is noted that responses are skewed towards the high-end of the scales, i.e. $(4=$ agree and $5=$ highly agree).

Table 1

Description of business opportunities pursued: frequency and percentage responses

\begin{tabular}{|l|c|c|c|c|}
\hline \multicolumn{1}{|c|}{ Question } & $\begin{array}{c}\mathbf{1} \\
\text { venture }\end{array}$ & $\begin{array}{c}\mathbf{2} \text { or } \mathbf{3} \\
\text { ventures }\end{array}$ & $\begin{array}{c}\text { 4 or more } \\
\text { ventures }\end{array}$ & $\begin{array}{c}\text { Total } \\
\text { respondents }\end{array}$ \\
\hline $\begin{array}{l}\text { 1. How many new, major businesses have you } \\
\text { pursued in the last five years? }\end{array}$ & 18 & 43 & 16 & 77 \\
\hline 2. How many of these new business & $23.4 \%$ & $55.8 \%$ & $20.8 \%$ & $100.0 \%$ \\
\hline $\begin{array}{l}\text { opportunities can be said to be successes? } \\
\text { H. }\end{array}$ & 28 & 49 & & 77 \\
\hline How many of these new business & $36.4 \%$ & $63.6 \%$ & $100.0 \%$ \\
\hline $\begin{array}{l}\text { opportunities were unrelated to the existing } \\
\text { business at the time? }\end{array}$ & 62 & 14 & & 76 \\
\hline
\end{tabular}

Table 3 displays the OPR variables as ranked by the number of businesses pursued in the last five years. In Table 3, the mean ranks are shown when the different variables are compared, using the Kruskal-Wallis test. The Kruskal-Wallis test is a one-way analysis of variance by ranks. It is interesting to note that the highest mean rank (46), for those respondents that have pursued one additional business opportunity, is on OPR item - "new business opportunities often arise in connection with a solution to a specific problem". The highest mean rank (41.87) for those respondents that have pursued two or three additional business opportunities is on OPR item - "my experience with new venture ideas results in both failures and successes". The highest mean rank (41.41) for those respondents that have pursued four or more additional business opportunities is on OPR item - "being creative is very important to identifying business opportunities".

Table 2

Percentage analysis for OPR and motivator items $(\mathrm{N}=77)$

\begin{tabular}{|l|c|c|c|c|c|c|}
\hline \multicolumn{1}{|c|}{ Variables } & $\begin{array}{c}\text { Highly } \\
\text { agree }\end{array}$ & Agree & Undecided & Disagree & $\begin{array}{c}\text { Highly } \\
\text { disagree }\end{array}$ & Total \\
\hline $\begin{array}{l}\text { OPR: } \\
\text { New business opportunities often } \\
\text { arise in connection with a solution } \\
\text { to a specific problem. }\end{array}$ & $37.7 \%$ & $51.9 \%$ & $5.2 \%$ & $3.9 \%$ & $1.3 \%$ & $100.0 \%$ \\
\hline $\begin{array}{l}\text { I listen extremely well to what } \\
\text { customers say they want and } \\
\text { don't want as a way of identifying } \\
\text { opportunities. }\end{array}$ & $49.4 \%$ & $41.6 \%$ & $5.2 \%$ & $2.6 \%$ & $1.3 \%$ & $100.0 \%$ \\
\hline
\end{tabular}




\begin{tabular}{|c|c|c|c|c|c|c|}
\hline $\begin{array}{l}\text { Being creative is very important to } \\
\text { identifying business opportunities. }\end{array}$ & $62.3 \%$ & $32.5 \%$ & $1.3 \%$ & $3.9 \%$ & & $100.0 \%$ \\
\hline $\begin{array}{l}\text { Identifying opportunities is } \\
\text { really several learning steps over } \\
\text { time, rather than a one-time } \\
\text { occurrence. }\end{array}$ & $39.0 \%$ & $50.6 \%$ & $9.1 \%$ & & $1.3 \%$ & $100.0 \%$ \\
\hline $\begin{array}{l}\text { My experience with new venture } \\
\text { ideas results in both failures and } \\
\text { successes. }\end{array}$ & $24.7 \%$ & $50.6 \%$ & $13.0 \%$ & $11.7 \%$ & & $100.0 \%$ \\
\hline $\begin{array}{l}\text { Other people bring new venture } \\
\text { business ideas to me. }\end{array}$ & $16.9 \%$ & $40.3 \%$ & $16.9 \%$ & $18.2 \%$ & $7.8 \%$ & $100.0 \%$ \\
\hline $\begin{array}{l}\text { Motivators for first venture: } \\
\text { Notice opportunities to develop a } \\
\text { business. }\end{array}$ & $50.6 \%$ & $45.5 \%$ & $2.6 \%$ & $1.3 \%$ & & $100.0 \%$ \\
\hline $\begin{array}{l}\text { Enjoyed exercising management } \\
\text { control and getting people to do } \\
\text { things. }\end{array}$ & $19.5 \%$ & $36.4 \%$ & $20.8 \%$ & $16.9 \%$ & $6.5 \%$ & $100.0 \%$ \\
\hline Wealth creation. & $42.1 \%$ & $44.7 \%$ & $9.2 \%$ & $3.9 \%$ & & $100.0 \%$ \\
\hline $\begin{array}{l}\text { Strong desire to work on their } \\
\text { own. }\end{array}$ & $40.3 \%$ & $45.5 \%$ & $10.4 \%$ & $3.9 \%$ & & $100.0 \%$ \\
\hline Did not want to retire. & $22.1 \%$ & $27.3 \%$ & $23.4 \%$ & $13.0 \%$ & $14.3 \%$ & $100.0 \%$ \\
\hline Needed to retain a job. & $11.7 \%$ & $41.6 \%$ & $23.4 \%$ & $16.9 \%$ & $6.5 \%$ & $100.0 \%$ \\
\hline $\begin{array}{l}\text { Always wanted to run own } \\
\text { company. }\end{array}$ & $48.1 \%$ & $41.6 \%$ & $5.2 \%$ & $3.9 \%$ & $1.3 \%$ & $100.0 \%$ \\
\hline Family. & $20.8 \%$ & $39.0 \%$ & $16.9 \%$ & $19.5 \%$ & $3.9 \%$ & $100.0 \%$ \\
\hline $\begin{array}{l}\text { Desire to avoid working for large } \\
\text { companies. }\end{array}$ & $19.5 \%$ & $31.2 \%$ & $22.1 \%$ & $19.5 \%$ & $7.8 \%$ & $100.0 \%$ \\
\hline $\begin{array}{l}\text { Wanted to have something to } \\
\text { hand down to others. }\end{array}$ & $27.3 \%$ & $32.5 \%$ & $18.2 \%$ & $15.6 \%$ & $6.5 \%$ & $100.0 \%$ \\
\hline $\begin{array}{l}\text { Motivations for successive } \\
\text { venture(s): } \\
\text { Desire to build up businesses and } \\
\text { add managerial skills. }\end{array}$ & $38.6 \%$ & $47.1 \%$ & $8.6 \%$ & $5.7 \%$ & & $100.0 \%$ \\
\hline $\begin{array}{l}\text { Money not as important, believed } \\
\text { they could control their personal } \\
\text { financial risk more effectively. }\end{array}$ & $10.0 \%$ & $38.6 \%$ & $25.7 \%$ & $21.4 \%$ & $4.3 \%$ & $100.0 \%$ \\
\hline $\begin{array}{l}\text { Personal commitment became } \\
\text { important. }\end{array}$ & $40.0 \%$ & $37.1 \%$ & $14.3 \%$ & $8.6 \%$ & & $100.0 \%$ \\
\hline Money prime motivation. & $28.6 \%$ & $52.9 \%$ & $11.4 \%$ & $5.7 \%$ & $1.4 \%$ & $100.0 \%$ \\
\hline $\begin{array}{l}\text { Ability to limit financial risk by } \\
\text { building up a new business in a } \\
\text { familiar sector. }\end{array}$ & $30.0 \%$ & $50.0 \%$ & $10.0 \%$ & $10.0 \%$ & & $100.0 \%$ \\
\hline
\end{tabular}




\begin{tabular}{|l|c|c|c|c|c|c|}
\hline $\begin{array}{l}\text { Wanted to repair and rebuild a } \\
\text { company rather than just make } \\
\text { money. }\end{array}$ & $14.3 \%$ & $31.4 \%$ & $15.7 \%$ & $31.4 \%$ & $7.1 \%$ & $100.0 \%$ \\
\hline $\begin{array}{l}\text { Desire to continue to build } \\
\text { something successful. }\end{array}$ & $50.0 \%$ & $34.3 \%$ & $5.7 \%$ & $5.7 \%$ & $4.3 \%$ & $100.0 \%$ \\
\hline $\begin{array}{l}\text { Enjoy the challenge of helping } \\
\text { companies grow, develop to their } \\
\text { full potential, and succeed. }\end{array}$ & $41.4 \%$ & $34.3 \%$ & $15.7 \%$ & $8.6 \%$ & & $100.0 \%$ \\
\hline
\end{tabular}

\section{Table 3}

OPR variables as ranked for number of businesses pursued

\begin{tabular}{|c|c|c|c|}
\hline OPR variables & $\begin{array}{l}\text { How many new, major } \\
\text { businesses have you pursued } \\
\text { in the last five years? }\end{array}$ & $\mathbf{N}$ & $\begin{array}{l}\text { Mean } \\
\text { rank }\end{array}$ \\
\hline \multirow{4}{*}{$\begin{array}{l}\text { New business opportunities often arise in connection } \\
\text { with a solution to a specific problem. }\end{array}$} & 1 & 18 & 46.00 \\
\hline & 2 or 3 & 43 & 38.87 \\
\hline & 4 or more & 16 & 31.47 \\
\hline & Total & 77 & \\
\hline \multirow{4}{*}{$\begin{array}{l}\text { I listen extremely well to what customers say } \\
\text { they want and don't want as a way of identifying } \\
\text { opportunities. }\end{array}$} & 1 & 18 & 35.06 \\
\hline & 2 or 3 & 43 & 39.97 \\
\hline & 4 or more & 16 & 40.84 \\
\hline & Total & 77 & \\
\hline \multirow{4}{*}{$\begin{array}{l}\text { Being creative is very important to identifying } \\
\text { business opportunities. }\end{array}$} & 1 & 18 & 40.72 \\
\hline & 2 or 3 & 43 & 37.38 \\
\hline & 4 or more & 16 & 41.41 \\
\hline & Total & 77 & \\
\hline \multirow{4}{*}{$\begin{array}{l}\text { Identifying opportunities is really several learning } \\
\text { steps over time, rather than a one-time occurrence. }\end{array}$} & 1 & 18 & 42.97 \\
\hline & 2 or 3 & 43 & 36.36 \\
\hline & 4 or more & 16 & 41.63 \\
\hline & Total & 77 & \\
\hline \multirow{4}{*}{$\begin{array}{l}\text { My experience with new venture ideas results in both } \\
\text { failures and successes. }\end{array}$} & 1 & 18 & 42.31 \\
\hline & 2 or 3 & 43 & 41.87 \\
\hline & 4 or more & 16 & 27.56 \\
\hline & Total & 77 & \\
\hline \multirow[t]{4}{*}{ Other people bring new venture business ideas to me. } & 1 & 18 & 44.58 \\
\hline & 2 or 3 & 43 & 38.70 \\
\hline & 4 or more & 16 & 33.53 \\
\hline & Total & 77 & \\
\hline
\end{tabular}


In order to test the first hypothesis that OPR will not differ depending on how many new, major businesses have been pursued; ChiSquare test statistics were conducted for the grouping of variables as per Table 3. Values were calculated using the asymptotic standard error assuming the null hypothesis. Only one variable is significant ( $\mathrm{p}$-value $<0.05$ ) with a Chi-Square $\left(\chi^{2}=6.206\right)$, this is for OPR item "my experience with new venture ideas results in both failures and successes".

Table 4 displays the motivator variables for reasons for the first venture as ranked by the number of businesses pursued in the last five years. Here the mean ranks are shown when the different variables are compared, using the Kruskal-Wallis test. The highest mean rank (43.28), for those respondents that have pursued one additional business opportunity, is for motivator - "desire to avoid working for large companies". In terms of those respondents that have pursued two or three additional business opportunities, the highest mean rank (42.64) is for the motivator "wealth creation". The highest mean rank (44.41) for those respondents that have pursued four or more additional business opportunities is for the motivator "family".

In order to test the first hypothesis that motivators will not differ depending on how many new, major businesses have been pursued; Chi-Square test statistics were conducted for the grouping of variables as per Table 4 . Values were calculated using the asymptotic standard error assuming the null hypothesis. No significant results were detected.

Table 5 displays the set of motivator variables which best describe reasons for the successive venture as ranked by the number of businesses pursued in the last five years. Here again the mean ranks are shown when the different variables are compared, using the Kruskal-
Wallis test. The highest mean rank (39.25), for those respondents that have pursued one additional business opportunity, is for motivator - "enjoy the challenge of helping companies grow, develop to their full potential, and succeed". In terms of those respondents that have pursued two or three additional business opportunities, the highest mean rank (39.42) is for the motivator "money prime motivator". The highest mean rank (36.69) for those respondents that have pursued four or more additional business opportunities is for the motivator "wanted to repair and rebuild a company rather than just make money".

In order to test the first hypothesis that motivators will not differ depending on how many new, major businesses have been pursued Chi-Square test statistics were conducted for the grouping of variables as per Table 5. Values were calculated using the asymptotic standard error assuming the null hypothesis. Across variables no significant results were detected.

Table 6 displays the results for OPR variables for number of business opportunities said to be successful. On this set of data descriptive statistics were calculated, i.e. mean scores and deviations based on two sizable categories that were under scrutiny. The highest mean scores are both on the last OPR variable "other people bring new venture business ideas to me" for when 1 or more than 1 of the new businesses can be said to be successful. To test hypothesis 2 , where OPR will not differ depending on how many of these businesses can be said to be successes, the following procedure was followed. In this instance the response set was adequate, and subsequently the Independent-samples t-test was conducted with the Levene's test for equality of variances, with the t-tests for equality of means. No significant differences across the OPR variables were detected. 


\section{Table 4}

Motivations for the first venture as ranked by number of businesses pursued

\begin{tabular}{|c|c|c|c|}
\hline Motivations for first venture & $\begin{array}{c}\text { How many new, major businesses } \\
\text { have you pursued in the last five } \\
\text { years? }\end{array}$ & $\mathbf{N}$ & Mean rank \\
\hline \multirow{4}{*}{$\begin{array}{l}\text { Notice opportunities to develop a } \\
\text { business. }\end{array}$} & 1 & 18 & 39.53 \\
\hline & 2 or 3 & 43 & 40.69 \\
\hline & 4 or more & 16 & 33.88 \\
\hline & Total & 77 & \\
\hline \multirow{4}{*}{$\begin{array}{l}\text { Enjoyed exercising management control } \\
\text { and getting people to do things. }\end{array}$} & 1 & 18 & 35.83 \\
\hline & 2 or 3 & 43 & 40.90 \\
\hline & 4 or more & 16 & 37.47 \\
\hline & Total & 77 & \\
\hline \multirow[t]{4}{*}{ Wealth creation. } & 1 & 18 & 29.33 \\
\hline & 2 or 3 & 42 & 42.64 \\
\hline & 4 or more & 16 & 37.94 \\
\hline & Total & 76 & \\
\hline \multirow[t]{4}{*}{ Strong desire to work on their own. } & 1 & 18 & 34.33 \\
\hline & 2 or 3 & 43 & 40.21 \\
\hline & 4 or more & 16 & 41.00 \\
\hline & Total & 77 & \\
\hline \multirow[t]{4}{*}{ Did not want to retire. } & 1 & 18 & 40.75 \\
\hline & 2 or 3 & 43 & 38.80 \\
\hline & 4 or more & 16 & 37.56 \\
\hline & Total & 77 & \\
\hline \multirow[t]{4}{*}{ Needed to retain a job. } & 1 & 18 & 36.58 \\
\hline & 2 or 3 & 43 & 39.33 \\
\hline & 4 or more & 16 & 40.84 \\
\hline & Total & 77 & \\
\hline \multirow[t]{4}{*}{ Always wanted to run own company. } & 1 & 18 & 41.28 \\
\hline & 2 or 3 & 43 & 37.81 \\
\hline & 4 or more & 16 & 39.63 \\
\hline & Total & 77 & \\
\hline
\end{tabular}




\begin{tabular}{|c|c|c|c|}
\hline \multirow[t]{4}{*}{ Family. } & 1 & 18 & 32.64 \\
\hline & 2 or 3 & 43 & 39.65 \\
\hline & 4 or more & 16 & 44.41 \\
\hline & Total & 77 & \\
\hline \multirow{4}{*}{$\begin{array}{l}\text { Desire to avoid working for large } \\
\text { companies. }\end{array}$} & 1 & 18 & 43.28 \\
\hline & 2 or 3 & 43 & 39.76 \\
\hline & 4 or more & 16 & 32.16 \\
\hline & Total & 77 & \\
\hline \multirow{4}{*}{$\begin{array}{l}\text { Wanted to have something to hand } \\
\text { down to others. }\end{array}$} & 1 & 18 & 39.19 \\
\hline & 2 or 3 & 43 & 39.12 \\
\hline & 4 or more & 16 & 38.47 \\
\hline & Total & 77 & \\
\hline
\end{tabular}

Table 5

Motivations for successive ventures as ranked by number of businesses pursued

\begin{tabular}{|c|c|c|c|}
\hline Motivations for successive ventures & $\begin{array}{c}\text { How many new, major businesses } \\
\text { have you pursued in the last five } \\
\text { years? }\end{array}$ & $\mathbf{N}$ & Mean rank \\
\hline \multirow{4}{*}{$\begin{array}{l}\text { Desire to build up businesses and add } \\
\text { managerial skills. }\end{array}$} & 1 & 12 & 26.50 \\
\hline & 2 or 3 & 42 & 38.19 \\
\hline & 4 or more & 16 & 35.19 \\
\hline & Total & 70 & \\
\hline \multirow{4}{*}{$\begin{array}{l}\text { Money not as important, believed they } \\
\text { could control their personal financial risk } \\
\text { more effectively. }\end{array}$} & 1 & 12 & 33.83 \\
\hline & 2 or 3 & 42 & 37.31 \\
\hline & 4 or more & 16 & 32.00 \\
\hline & Total & 70 & \\
\hline \multirow{4}{*}{$\begin{array}{l}\text { Personal commitment became } \\
\text { important. }\end{array}$} & 1 & 12 & 33.25 \\
\hline & 2 or 3 & 42 & 37.33 \\
\hline & 4 or more & 16 & 32.38 \\
\hline & Total & 70 & \\
\hline \multirow[t]{4}{*}{ Money prime motivation. } & 1 & 12 & 29.00 \\
\hline & 2 or 3 & 42 & 39.42 \\
\hline & 4 or more & 16 & 30.09 \\
\hline & Total & 70 & \\
\hline
\end{tabular}




\begin{tabular}{|c|c|c|c|}
\hline \multirow{4}{*}{$\begin{array}{l}\text { Ability to limit financial risk by building } \\
\text { up a new business in a familiar sector. }\end{array}$} & 1 & 12 & 33.75 \\
\hline & 2 or 3 & 42 & 37.00 \\
\hline & 4 or more & 16 & 32.88 \\
\hline & Total & 70 & \\
\hline \multirow{4}{*}{$\begin{array}{l}\text { Wanted to repair and rebuild a company } \\
\text { rather than just make money. }\end{array}$} & 1 & 12 & 28.46 \\
\hline & 2 or 3 & 42 & 37.06 \\
\hline & 4 or more & 16 & 36.69 \\
\hline & Total & 70 & \\
\hline \multirow{4}{*}{$\begin{array}{l}\text { Desire to continue to build something } \\
\text { successful. }\end{array}$} & 1 & 12 & 35.21 \\
\hline & 2 or 3 & 42 & 36.06 \\
\hline & 4 or more & 16 & 34.25 \\
\hline & Total & 70 & \\
\hline \multirow{4}{*}{$\begin{array}{l}\text { Enjoy the challenge of helping companies } \\
\text { grow, develop to their full potential, and } \\
\text { succeed. }\end{array}$} & 1 & 12 & 39.25 \\
\hline & 2 or 3 & 42 & 36.79 \\
\hline & 4 or more & 16 & 29.31 \\
\hline & Total & 70 & \\
\hline
\end{tabular}

Table 6

OPR variables for number of businesses said to be successful: descriptive analysis

\begin{tabular}{|c|c|c|c|c|}
\hline OPR variables & $\begin{array}{l}\text { How many of these new } \\
\text { business opportunities can } \\
\text { be said to be successes? }\end{array}$ & Mean & $\begin{array}{c}\text { Std. } \\
\text { deviation }\end{array}$ & $\begin{array}{l}\text { Std. } \\
\text { error } \\
\text { mean }\end{array}$ \\
\hline \multirow{2}{*}{$\begin{array}{l}\text { New business opportunities often arise in } \\
\text { connection with a solution to a specific } \\
\text { problem. }\end{array}$} & 1 & 2.00 & 0.903 & 0.171 \\
\hline & More than 1 & 1.67 & 0.747 & 0.107 \\
\hline \multirow{2}{*}{$\begin{array}{l}\text { I listen extremely well to what customers } \\
\text { say they want and don't want as a way of } \\
\text { identifying opportunities. }\end{array}$} & 1 & 1.61 & 0.629 & 0.119 \\
\hline & More than 1 & 1.67 & 0.899 & 0.128 \\
\hline \multirow{2}{*}{$\begin{array}{l}\text { Being creative is very important to } \\
\text { identifying business opportunities. }\end{array}$} & 1 & 1.50 & 0.694 & 0.131 \\
\hline & More than 1 & 1.45 & 0.738 & 0.105 \\
\hline \multirow{2}{*}{$\begin{array}{l}\text { Identifying opportunities is really several } \\
\text { learning steps over time, rather than a } \\
\text { one-time occurrence. }\end{array}$} & 1 & 1.79 & 0.630 & 0.119 \\
\hline & More than 1 & 1.71 & 0.791 & 0.113 \\
\hline \multirow{2}{*}{$\begin{array}{l}\text { My experience with new venture ideas } \\
\text { results in both failures and successes. }\end{array}$} & 1 & 2.14 & 0.932 & 0.176 \\
\hline & More than 1 & 2.10 & 0.918 & 0.131 \\
\hline \multirow{2}{*}{$\begin{array}{l}\text { Other people bring new venture business } \\
\text { ideas to me. }\end{array}$} & 1 & 2.61 & 1.066 & 0.201 \\
\hline & More than 1 & 2.59 & 1.273 & 0.182 \\
\hline
\end{tabular}


Table 7 displays the results for motivations for first venture for number of business opportunities said to be successful. Following the same procedure as previously, mean scores and deviations were calculated. The mean scores tend to be below the scale midpoint. Interestingly the highest mean score is for the motivator "needed to retain a job". The standard error of mean column indicates the measure of distribution of sample means and is the standard deviation of the distribution (Cooper \& Emory, 1995).

To test hypothesis 2 , where motivations will not differ depending on how many of these businesses can be said to be successes, the same procedure as for the OPR items was followed, and one significant difference on the item "needed to retain a job" for first venture motivators was detected.

Table 8 displays the results for motivations for successive ventures by number of business opportunities said to be successful. Following the same procedure as for the previous set of motivators, descriptives were calculated. The mean scores again tend to be below the scale midpoint, with a single high mean score when more than 1 business is successful (3.10) for the item "wanted to repair and rebuild a company rather than just make money". Testing hypothesis 2 revealed one significant difference ( $\mathrm{p}$-value $<0.05$ ) for the same motivator "wanted to repair and rebuild company rather than make money".

\section{Table 7}

Motivations for first venture by number of businesses said to be successful: descriptives

\begin{tabular}{|c|c|c|c|c|}
\hline Motivations for first venture & $\begin{array}{l}\text { How many of these } \\
\text { new business } \\
\text { opportunities } \\
\text { can be said to be } \\
\text { successes? }\end{array}$ & Mean & $\begin{array}{l}\text { Std. } \\
\text { deviation }\end{array}$ & $\begin{array}{l}\text { Std. error } \\
\text { mean }\end{array}$ \\
\hline \multirow{2}{*}{$\begin{array}{l}\text { Notice opportunities to develop a } \\
\text { business. }\end{array}$} & 1 & 1.57 & 0.573 & 0.108 \\
\hline & More than 1 & 1.53 & 0.649 & 0.093 \\
\hline \multirow{2}{*}{$\begin{array}{l}\text { Enjoyed exercising management control } \\
\text { and getting people to do things. }\end{array}$} & 1 & 2.36 & 1.193 & 0.225 \\
\hline & More than 1 & 2.65 & 1.165 & 0.166 \\
\hline \multirow[t]{2}{*}{ Wealth creation. } & 1 & 1.70 & 0.823 & 0.158 \\
\hline & More than 1 & 1.78 & 0.771 & 0.110 \\
\hline \multirow[t]{2}{*}{ Strong desire to work on their own. } & 1 & 1.61 & 0.629 & 0.119 \\
\hline & More than 1 & 1.88 & 0.857 & 0.122 \\
\hline \multirow[t]{2}{*}{ Did not want to retire. } & 1 & 2.68 & 1.307 & 0.247 \\
\hline & More than 1 & 2.71 & 1.369 & 0.196 \\
\hline \multirow[t]{2}{*}{ Needed to retain a job. } & 1 & 2.50 & 0.839 & 0.159 \\
\hline & More than 1 & 2.73 & 1.221 & 0.174 \\
\hline \multirow[t]{2}{*}{ Always wanted to run own company. } & 1 & 1.54 & 0.693 & 0.131 \\
\hline & More than 1 & 1.78 & 0.919 & 0.131 \\
\hline \multirow[t]{2}{*}{ Family. } & 1 & 2.43 & 1.136 & 0.215 \\
\hline & More than 1 & 2.49 & 1.157 & 0.165 \\
\hline
\end{tabular}




\begin{tabular}{|l|c|c|c|c|}
\hline \multirow{2}{*}{$\begin{array}{l}\text { Desire to avoid working for large } \\
\text { companies. }\end{array}$} & $\mathbf{1}$ & 2.68 & 1.362 & 0.257 \\
\cline { 2 - 5 } & More than 1 & 2.63 & 1.149 & 0.164 \\
\hline $\begin{array}{l}\text { Wanted to have something to hand down } \\
\text { to others. }\end{array}$ & $\mathbf{1}$ & 2.36 & 1.193 & 0.225 \\
\cline { 2 - 5 } & More than 1 & 2.45 & 1.259 & 0.180 \\
\hline
\end{tabular}

\section{Table 8}

Motivations for successive ventures by number of businesses said to be successful

\begin{tabular}{|c|c|c|c|c|}
\hline Motivations for successive ventures & $\begin{array}{l}\text { How many of these } \\
\text { new business } \\
\text { opportunities can be } \\
\text { said to be successes? }\end{array}$ & Mean & $\begin{array}{l}\text { Std. } \\
\text { deviation }\end{array}$ & $\begin{array}{l}\text { Std. error } \\
\text { mean }\end{array}$ \\
\hline \multirow{2}{*}{$\begin{array}{l}\text { Desire to build up businesses and add } \\
\text { managerial skills. }\end{array}$} & 1 & 1.59 & 0.590 & 0.126 \\
\hline & More than 1 & 1.92 & 0.895 & 0.129 \\
\hline \multirow{2}{*}{$\begin{array}{l}\text { Money not as important, believed they } \\
\text { could control their personal financial risk } \\
\text { more effectively. }\end{array}$} & 1 & 2.68 & 1.041 & 0.222 \\
\hline & More than 1 & 2.73 & 1.067 & 0.154 \\
\hline \multirow[t]{2}{*}{ Personal commitment became important. } & 1 & 2.05 & 0.950 & 0.203 \\
\hline & More than 1 & 1.85 & 0.945 & 0.136 \\
\hline \multirow[t]{2}{*}{ Money prime motivation. } & 1 & 2.09 & 0.921 & 0.196 \\
\hline & More than 1 & 1.94 & 0.861 & 0.124 \\
\hline \multirow{2}{*}{$\begin{array}{l}\text { Ability to limit financial risk by building } \\
\text { up a new business in a familiar sector. }\end{array}$} & 1 & 1.91 & 0.610 & 0.130 \\
\hline & More than 1 & 2.04 & 1.010 & 0.146 \\
\hline \multirow{2}{*}{$\begin{array}{l}\text { Wanted to repair and rebuild a company } \\
\text { rather than just make money. }\end{array}$} & 1 & 2.32 & 1.041 & 0.222 \\
\hline & More than 1 & 3.10 & 1.225 & 0.177 \\
\hline \multirow{2}{*}{$\begin{array}{l}\text { Desire to continue to build something } \\
\text { successful. }\end{array}$} & 1 & 1.59 & 0.666 & 0.142 \\
\hline & More than 1 & 1.90 & 1.207 & 0.174 \\
\hline \multirow{2}{*}{$\begin{array}{l}\text { Enjoy the challenge of helping companies } \\
\text { grow, develop to their full potential, and } \\
\text { succeed. }\end{array}$} & 1 & 1.86 & 0.710 & 0.151 \\
\hline & More than 1 & 1.94 & 1.060 & 0.153 \\
\hline
\end{tabular}

For the final data set, again due to sampling inadequacy, the non-parametric alternative was used and Mann-Whitney tests with mean rank and sum of ranks for the different groupings are reported in Table 9 (only the OPR variables are tabulated, the motivators are not shown due to space constraints). This test is an alternative to the t-test without the latter's limiting assumptions (Cooper \& Emory, 1995). Here one can test for samples that are unequal, as was the case. After the mean ranking, the rank values for each sample are totalled, see last column in Table 9 - sum of ranks. To test hypothesis 3 , where OPR and motivations will not differ depending on how many of these businesses were unrelated to an existing business at the time, test statistics included the Mann-Whitney U, the Wilcoxon $\mathrm{W}$, and the $\mathrm{Z}$ test. Values were calculated using the asymptotic standard error assuming the null hypothesis. No significant differences were detected across variables. 


\section{Table 9}

OPR variables as ranked by number of unrelated businesses pursued

\begin{tabular}{|c|c|c|c|c|}
\hline OPR variables & $\begin{array}{l}\text { How many of these new } \\
\text { business opportunities } \\
\text { were unrelated to the } \\
\text { existing business at the } \\
\text { time? }\end{array}$ & $\mathbf{N}$ & $\begin{array}{l}\text { Mean } \\
\text { Rank }\end{array}$ & $\begin{array}{l}\text { Sum of } \\
\text { Ranks }\end{array}$ \\
\hline \multirow{3}{*}{$\begin{array}{l}\text { New business opportunities often } \\
\text { arise in connection with a solution to a } \\
\text { specific problem. }\end{array}$} & 1 & 62 & 38.52 & 2388.50 \\
\hline & More than 1 & 14 & 38.39 & 537.50 \\
\hline & Total & 76 & & \\
\hline \multirow{3}{*}{$\begin{array}{l}\text { I listen extremely well to what } \\
\text { customers say they want and } \\
\text { don't want as a way of identifying } \\
\text { opportunities. }\end{array}$} & 1 & 62 & 39.20 & 2430.50 \\
\hline & More than 1 & 14 & 35.39 & 495.50 \\
\hline & Total & 76 & & \\
\hline \multirow{3}{*}{$\begin{array}{l}\text { Being creative is very important to } \\
\text { identifying business opportunities. }\end{array}$} & 1 & 62 & 39.69 & 2460.50 \\
\hline & More than 1 & 14 & 33.25 & 465.50 \\
\hline & Total & 76 & & \\
\hline \multirow{3}{*}{$\begin{array}{l}\text { Identifying opportunities is really } \\
\text { several learning steps over time, rather } \\
\text { than a one-time occurrence. }\end{array}$} & 1 & 62 & 39.23 & 2432.00 \\
\hline & More than 1 & 14 & 35.29 & 494.00 \\
\hline & Total & 76 & & \\
\hline \multirow{3}{*}{$\begin{array}{l}\text { My experience with new venture ideas } \\
\text { results in both failures and successes. }\end{array}$} & 1 & 62 & 40.48 & 2510.00 \\
\hline & More than 1 & 14 & 29.71 & 416.00 \\
\hline & Total & 76 & & \\
\hline \multirow{3}{*}{$\begin{array}{l}\text { Other people bring new venture } \\
\text { business ideas to me. }\end{array}$} & 1 & 62 & 38.94 & 2414.50 \\
\hline & More than 1 & 14 & 36.54 & 511.50 \\
\hline & Total & 76 & & \\
\hline
\end{tabular}

\section{0}

\section{Conclusion}

Based on the empirical results, the null hypotheses are accepted, as there is no evidence of significant differences between the study variables. A broad interpretation of the findings is that the opportunity recognition behaviours and motivators do not differ among serial entrepreneurs regardless of how many new, major businesses have been pursued, or whether they can be said to be successes, or whether they were unrelated to the existing business at that time. Serial entrepreneurs it seems are continually pursuing new business opportunities, and relying on the OPR process for a variety of reasons.

Nonetheless, a few scattered items did indicate significant differences, for instance OPR differed with respect to how many new, major businesses have been pursued, on one criterion "experiences with new venture ideas result in both failures and successes". A plausible interpretation is that serial entrepreneurs are not afraid to make mistakes; failures and false starts are a normal part of OPR and the knowledge gained from such experiences often leads to future gains that are more solid (Lumpkin, Hills \& Shrader, 2004: 85). 
In terms of motivators which may differ based on how many businesses can be called successes, significant differences were detected on "need to retain a job", and "wanting to repair and rebuild company rather than make money". These results may be interpreted in light of the suggestions by Westhead and Wright (1998) who argue that there may or may not be a reduction in the emphasis on financial returns in subsequent ventures and that personal motivations and resources influence the OPR. Applied to the task of opportunity recognition, it has been proposed that a deeper understanding of the motivating influence of potential financial reward on opportunity recognition requires the concomitant consideration of prior knowledge (Taplin, 2004: 244). However, even if an individual is motivated to recognise opportunities, the act of opportunity recognition is unlikely unless he or she has the prior knowledge to do so. Amabile (1997: 42) contends that "expertise (factual knowledge and technical proficiency) is the foundation for all creative work" - a major element in OPR.

Clearly, opportunity recognition is best viewed as a multi-stage and often complex phenomenon that is influenced by numerous motivators and factors (Lumpkin, Hills \& Shrader, 2004). To be scientific is to be parsimonious and consequently this study examined those variables reported to be most relevant to OPR and motivators for serial entrepreneurs. Although there can be a wide variety of contextual as well as individual factors that influence the serial entrepreneur, the role of OPR has been emphasised as a key issue that serial entrepreneurs are generally adept at (Taplin, 2004).

\section{1}

\section{Implications}

This initial South African interrogation into OPR of serial entrepreneurs advances the topic where very few, if any studies have been conducted and where there is virtually no theoretical discourse concerning serial entrepreneurship in an emerging country context (Taplin, 2004). Entrepreneurship has no great theories; at best concepts are taken from other fields and then incorporated into process models (Bygrave \& Hofer, 1991). By empirically testing hypotheses and pointing to several areas of interest to entrepreneurs and policy makers, where much speculation exists, this study makes a modest contribution to theory building and demonstrates the complementary nature of the constructs investigated and their combined explanatory potential in understanding serial entrepreneurship. Apart from theoretical implications, the study has several important implications for practioners, educators and policy makers.

South Africa has a dual-logic economy, where on the one side there is a highly developed economic sector and on the other side one struggling for survival. This schism means that entpreneurial activity in South Africa is heavily skewed toward low-expectation entrepreneurial activity, often described as survivalist firms, characterised by necessity rather than opportunity focused (Maas \& Herrington, 2007). Opportunity-focused entrepreneurship has been found to differ systematically from necessity-driven entrepreneurs in terms of (1) expectations of job creation (2) projections for out-of-country exports (3) intention to replicate existing business activity versus creating a new niche (McMullen, Bagby \& Palich, 2008). Understanding opportunity recognition behaviours and reasons for engaging in serial entrepreneurship would assist national policy makers who are trying to encourage more opportunity focused entrepreneurial behaviour.

Recognising that business opportunities and having confidence in personal skills to implement a business may be enhanced through education and training, there is evidence suggesting that those with more education are more likely to pursue high-growth opportunity entrepreneurship (Corbett, 2007). Teaching opportunity recognition skills is a particularly important component of entrepreneurship education, and it is recommended that educators incorporate OPR into the syllabus. The scholarly pursuit of entrepreneurship would be to understand how opportunities are discovered and by whom and with what consequences.

Recalling that the present study reports a significant difference on OPR item "my 
experience with new venture ideas results in both failures and successes", it seems plausible to argue that OPR involves experimentation and Vesper (1996) has suggested that one way to test the viability of a new concept is to launch the business and see what happens. For serial entrepreneurs this is recommended in the context of ventures that have few start-up costs and low downside risks; the cost of launching a venture may actually be less that the cost of extensive market research and or product testing (Lumpkin, Hills \& Shrader, 2004).

\section{2}

\section{Limitations and future research}

Limitations of the present study include the measures of behaviours and motivators which are retrospective self-reports concerning OPR activity and motivations. These self-assessments may not accurately reflect OPR behaviour, and are prone to cognitive and motivational bias. Moreover the results may have been affected by a reduction in statistical power through the use of some categorical variables.

Based on the very limited population data available on this category of entrepreneurs future research may wish to include more demographic and contextual variables, e.g., prior experience, social networks, industry type, and venture size to develop an integrated framework for conceptualising serial entrepreneurs.

Clearly, more and more scholars today are underscoring the critical importance of opportunity to entrepreneurship (Gaglio \& Katz, 2001; Taplin, 2004; Lumpkin, Hills \& Shrader, 2004), and several gaps are currently missing in the literature, which provides fertile ground for future research. Research could focus on OPR methods used by serial entrepreneurs - does the process speed up and get easier as serial entrepreneurs gain more ventures? Do serial entrepreneurs use similar cognitions to novice entrepreneurs? Do serial entrepreneurs have unique network structures? Do serial entrepreneurs start more ventures during economic downturns?

\section{References}

ALVAREZ, S.A. \& BUSENITZ, L.W. 2001. The entrepreneurship of resource-based theory. Journal of Management, 27: 755-775.

AMABILE, T.M. 1997. Motivating creativity in organisations: on doing what you love and loving what you do. California Management Review, 40: 39-57. ARDICHVILI, A. CARDOZA, R. \& RAY, S. 2003. A theory of entrepreneurial opportunity identification and development. Journal of Business Venturing, 18: 105-123.

BHAVE, M. 1994. A process model of entrepreneurial venture creation. Journal of Business Venturing, 9: 223-242.

BIRLEY, S. \& WESTHEAD, P. 1994. Taxonomy of business start-up reasons and their impact on firm growth and size. Journal of Business Venturing, 9: 7-32. BYGRAVE, W. \& HOFER, C. 1991. Theorising about entrepreneurship. Entrepreneurship Theory and Practice, 15: 7-25.

CHANDLER, G., LYON, D. \& DETIENNE, D. 2005. Antecedents and exploitation outcomes of opportunity identification processes, presented at the National Academy of Management Best Paper Proceedings. Honolulu, April.

CHRISTENSEN, P.S. \& PETERSON, R. 1990.

Opportunity identification: mapping the sources of new venture ideas, paper presented at the $10^{\text {th }}$ annual Babson College Entrepreneurship Research Conference, Aarhus, Denmark. June.

COOPER, R.D. \& EMORY, C.W. 1995. Business research methods $\left(5^{\text {th }}\right.$ ed.). Chicago: Irwin Inc. CORBETT, A.C. 2007. Learning symmetries and the discovery of entrepreneurial opportunities. Journal of Business Venturing, 22: 97-118.

DAVIDSSON, P. 2004. Researching entrepreneurship, International Studies in Entrepreneurship. New York: Springer.

DAVIDSSON, P. \& HONIG, B. 2003. The role of social and human capital among nascent entrepreneurs. Journal of Business Venturing, 18: 301-331.

DE TIENNE, D.R. \& CHANDLER, G.N. 2004.

Opportunity identification and its role in the entrepreneurial classroom: a pedagogical approach and empirical test. Academy of Management Learning and Education, 3: 242-257.

DIMOV, D. 2007. Beyond the single-person insight attribution in understanding entrepreneurial opportunities. Entrepreneurship Theory and Practice, Sept: 713-731.

DOUGLAS, E.J. \& SHEPHERD, D.A. 2003.

Self-employment as a career choicer: attitudes, 
entrepreneurial intentions and utility maximization.

Entrepreneurship Theory and Practice, 26: 81-90.

DRUCKER, P. 1998. The discipline of innovation.

Harvard Business Review. 80: 95-101.

FELDMAN, D. 2004. What are we talking about when we talk about theory? Journal of Management, 30:

565-567.

GAGLIO, C.M. \& KATZ, J. 2001. The psychological basis of opportunity identification: entrepreneurial alertness. Journal of Small Business Economics, 16: 95-111.

GARTNER, W.B. 1989. Some suggestions for research on entrepreneurial traits and characteristics. Entrepreneurship Theory and Practice, Fall: 27-37. GARTNER, W.B. 1990. What are we talking about when we talk about entrepreneurship. Journal of Business Venturing, 5: 15-28.

HILLS, G. SCHRADER, R, \& LUMPKIN, T. 1999.

Opportunity recognition as a creative process. Frontiers of Entrepreneurship Research, 12: 216-227.

HILLS, G.E. \& SINGH, R.P. 2004. Opportunity recognition (pp. 259-271), in Gartner, W.B., Shaver, K.G., Carter, N.M. \& Reynolds, P.D. (eds.). 2004.

Handbook of entrepreneurial dynamics. California: Sage Publications.

KAISH, S. \& GILAD, B. 1991. Characteristics of opportunity search for entrepreneurs versus executives: sources, interests, and general alertness. Journal of Business Venturing. 6: 45-61.

KOURILSKY, M.L. 1995. Entrepreneurship education: opportunity in search of curriculum. Business Education Forum, 50: 11-15.

KRUEGER, N.F. 2000. The cognitive infrastructure of opportunity emergence. Entrepreneurship Theory and

Practice, 24: 5-23.

LOW, M. \& MACMILLAN, I. 1988. Entrepreneurship: past research and future challenges. Journal of

Management. 14: 139-162.

LUMPKIN, G.T. \& DESS, G.G. 1996. Clarifying the entrepreneurial orientation construct and linking it to performance. Academy of Management Review. 21: 12-32.

LUMPKIN, G.T, HILLS, G.E. \& SHRADER, R.C. 2004. Opportunity recognition (pp. 78-89), in Welsch, H. (ed.). Entrepreneurship: The road ahead. London: Routledge.

MAAS, G. \& HERRINGTON, M. 2007. South African Report: global entrepreneurship monitor. UCT, South Africa: Graduate School of Business.
MCMULLEN, S.J., BAGBY, D.R. \& PALICH, L.E. 2008. Economic freedom and the motivation to engage in entrepreneurial action. Entrepreneurship Theory and Practice, September: 875-895.

SHANE, S. 2000. A general theory of entrepreneurship. The individual-opportunity nexus. Entrepreneurship education series. USA: Edward Elgar.

SHANE, S. \& VENKATARAMAN, S. 2000. The promise of entrepreneurship as a field of research. Academy of Management Review, 25: 217-235. SHANE, S. \& VENKATARAMAN, S. 2001. Entrepreneurship as a field of research: a response to Zahra \& Dess, Singh, \& Erikson. Academy of Management Review, 26: 13-18.

SHEPHERD, D.A. \& DETIENNE, D.R. 2005. Prior knowledge, potential financial reward, and opportunity identification. Entrepreneurship Theory and Practice, 6: 91-112.

SINGH, R.P. 2000. Entrepreneurial Opportunity Recognition through Social Networks. New York: Garland.

SOUTH AFRICA BUSINESS GUIDEBOOK.

2005/6. Your essential A-Z business resources with an investment focus ( $9^{\text {th }}$ ed.). South Africa: Write Stuff Publishing.

STREET, C.T. \& CAMERON, A.F. 2007. External relationships and small business: a review of small business alliance and network research. Journal of Small Business Management, 45(2): 239-266.

TAPLIN, S. 2004. Serial entrepreneurs: An in-depth look at the phenomenon of habitual entrepreneurs (pp. 240-252), in Welsch, H. (ed.). Entrepreneurship: The road ahead. London: Routledge.

TIMMONS, J.A. 1994. New venture creation (4 $4^{\text {th }}$ ed.). USA: Irwin.

UCBASARAN, D., WESTHEAD, P. \& WRIGHT, M. 2001. The focus of entrepreneurial research: contextual and process issues. Entrepreneurship Theory and Practice, 25: 34-45.

VENKATARAMAN, S. 1997. The distinctive domain of entrepreneurship research. Advances in Entrepreneurship, Firm Emergence and Growth, 3: 119-138.

VESPER, K.H. 1996. New Venture Experience (rev. ed.). Seattle: Vector Books.

WESTHEAD, P. \& WRIGHT, M. 1998. Novice, portfolio and serial founders located in rural and urban areas. Entrepreneurship Theory and Practice. 22: 63-100. WRIGHT, M., WESTHEAD, P. \& SOHL, J.

1997. Habitual entrepreneurs and angel investors. Entrepreneurship Theory and Practice, 22: 5-21. 